\title{
Italian literary archives: legacies and challenges
}

Book or Report Section

Published Version

Creative Commons: Attribution-Noncommercial-No Derivative Works 4.0

Open Access

La Penna, D. (2018) Italian literary archives: legacies and challenges. In: Sutton, D. C. and Livingstone, A. (eds.) The future of literary archives: diasporic and dispersed collections at risk. ARC, pp. 89-101. ISBN 9781942401575 Available at https://centaur.reading.ac.uk/76400/

It is advisable to refer to the publisher's version if you intend to cite from the work. See Guidance on citing.

Publisher: ARC

All outputs in CentAUR are protected by Intellectual Property Rights law, including copyright law. Copyright and IPR is retained by the creators or other copyright holders. Terms and conditions for use of this material are defined in the End User Agreement.

\section{www.reading.ac.uk/centaur}

\section{CentAUR}

Central Archive at the University of Reading

Reading's research outputs online 
THE FUTURE OF LITERARY ARCHIVES 


\section{COLLECTION DEVELOPMENT, CULTURAL HERITAGE, AND DIGITAL HUMANITIES}

This series publishes both monographs and edited thematic collections in the broad areas of cultural heritage, digital humanities, collecting and collections, public history, and allied areas of applied humanities. In the spirit of our mission to take a stand for the humanities, this series illustrates humanities research keeping pace with technological innovation, globalization, and democratization. We value a variety of established, new, and diverse voices and topics in humanities research, and this series provides a platform for publishing the results of cutting-edge projects within these fields.

The aim is to illustrate the impact of humanities research and in particular reflect the exciting new networks developing between researchers and the cultural sector, including archives, libraries and museums, media and the arts, cultural memory and heritage institutions, festivals and tourism, and public history.

\section{Acquisitions Editor}

Danièle Cybulskie

\section{Evaluation and Peer Review}

The press has every proposal independently evaluated by expert reviews before any formal commitment is made by the press to the author. Further, all submitted manuscripts are subject to peer review by an expert chosen by the press. 


\title{
THE FUTURE OF LITERARY ARCHIVES: DIASPORIC AND DISPERSED COLLECTIONS AT RISK
}

\author{
Edited by
}

DAVID C. SUTTON with ANN LIVINGSTONE 


\section{British Library Cataloguing in Publication Data}

A catalogue record for this book is available from the British Library

\section{(C) 2018, Arc Humanities Press, Leeds}

cc) (i) $\fallingdotseq$ (5) This work is licensed under a Creative Commons Attribution-

NonCommercial- NoDerivatives 4.0 International Licence.

The author asserts their moral right to be identified as the author of their part of this work.

Permission to use brief excerpts from this work in scholarly and educational works is hereby granted provided that the source is acknowledged. Any use of material in this work that is an exception or limitation covered by Article 5 of the European Union's Copyright Directive (2001/29/EC) or would be determined to be "fair use" under Section 107 of the U.S. Copyright Act September 2010 Page 2 or that satisfies the conditions specified in Section 108 of the U.S. Copyright Act (17 USC §108, as revised by P.L. 94-553) does not require the Publisher's permission.

ISBN: 9781942401575

e-ISBN: 9781942401582

\section{https://arc-humanities.org}

Printed and bound by CPI Group (UK) Ltd, Croydon, CR0 4YY 


\section{Chapter 8}

\section{ITALIAN LITERARY ARCHIVES: LEGACIES AND CHALLENGES}

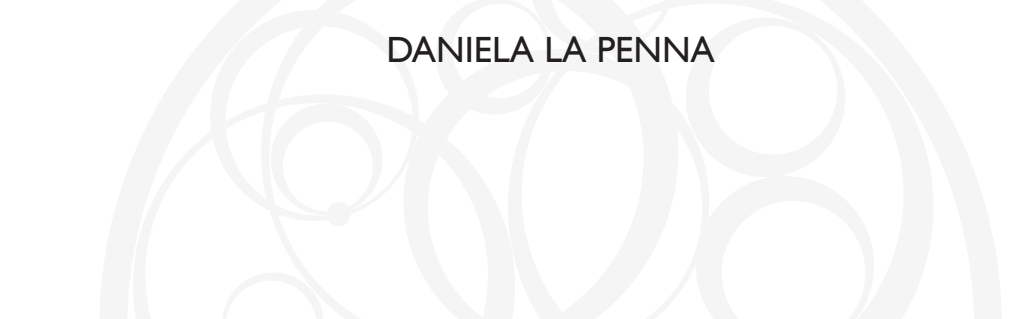

\section{Synergies and Scope}

Published two years apart, Jacques Derrida's Archive Fever and Maria Corti's Ombre dal fondo illuminate our understanding of the complexities of the Archive in complementary fashions. In his 1995 essay, the French philosopher addresses the "radical finitude, [...] the possibility of forgetfulness" inherent in what he calls the "archive drive," a response to the death drive that defines our collective engagement with memory and its preservation (Derrida, 1995,18). As is customary, the etymological roots of the word Archive are exposed, their semantic productivity stoked: simultaneously linked to Arkhé, the locus of origin, and to Arkheion, the place where magistrates would preserve and make available the texts of the law, the Archive in Derrida's semantic slippage is inherently linked to justice, memory, and writing. ${ }^{1}$ The Archive is presented as a place of longing and coercion, thus allowing archive fever to be defined as "an irrepressible desire to return to the origin, a homesickness, a nostalgia for the return to the most archaic place of absolute commencement" (Derrida, 1995, 91). Published in 1997 by scholar and novelist Maria Corti, Ombre dal fondo also describes the Archive as a place of haunting, where scholars confront the materiality of traces compounding the avant-texte, both of those works of literature that were delivered to the reader experience and those texts, postulating a multitude of possibilities, that would never be brought to completion, whether by accident or intention. Both Archive Fever and Ombre dal fondo take their cue from localized embodiments of the Archive: the Freud archive in London for

I According to Derrida, Arkhé is a term where authority and origin are linked together: "[Arkhé] apparently coordinates two principles in one: the principle according to nature or history, there where things commence-physical, historical, or ontological principle-but also the principle according to the law, there where men and gods command, there where authority, social order are exercised, in this place from which order is given-nomological principle" (Derrida, 1995, 1). For a discussion of the cultural significance of Derrida's text, see Brian Treanor, "What Tradition? Whose Archive? Blogs, Googlewashing, and the Digitization of the Archive," Analecta Hermeneutica 1 (2009): 231-41. 
Derrida, and the Centro per gli studi sulla tradizione manoscritta di autori moderni e contemporanei in Pavia for Corti, its conceiver, founder, and indefatigable director for over twenty years. ${ }^{2}$ It is the Archive rooted in a specific geography and sheltering a specific set of documents that drives their consideration of the way archives affect our ability to conceive of the past and conceptualize our relationship to the future. Both scholars come to terms with the Archive as a place where opposing conceptions of time meet: for Corti the Archive is the place where aion (the time of finitude, of a life ended) and chronos (the time that extends into the future) compete with one another (Corti, 1997, 7). For Derrida, the archive is not only "the place for stocking and conserving an archivable content of the past. [It] also determines the structure of the archivable content even in its very coming into existence and its relationship to the future" (Derrida, 1995, 17). In Corti's Ombre dal fondo, the papers archived in the Centro are given a new lease of life by scholarly dedication, and hitherto unheard of convergences can be discovered between the papers and the correspondence of the many authors which have found their new domicile within the walls of the Centro Corti single-handedly built. The delicate anthropology of learning, described by Corti, hinges on a notion of the Archive powerfully articulated by Derrida, and intended as both "memorial" and "reminder" of the past (Derrida, 1995, 23). Derrida's Archive is the place where we shore up against the ruinous experience of time and death, a place where we can gather and collect only what is left behind (the ironic and tragic supplementary nature of the archival document not only in relation to the event but also to the other types of evidence pulverized by destruction, what Derrida calls the "ash of the archive") (Derrida, 1995, 91). This view is given an empirical translation in Corti's "archontic" struggle to build a home for authors' papers, increasingly acting as Arkheion against dispersal and material obliteration. Each collection located in Pavia reveals to Corti the paradox of the Archive: the documents surviving the author's destructive drive (and relatives' neglect, protective jealousy, or greed) are a permanent memento of those which have been destroyed, the very existence of the former a powerful reminder of the extinction of the latter. This paradox leads to another: filiation and domiciliation are not exclusively bound together. The author's material traces can be scattered across various domiciles, preserved in different archives, in multiple territories and jurisdictions. The centrifugal power of dispersal, whatever caused it, is yet another reminder that the principle of universality to which the authority of the Archive aspires is hollow: archival jurisdiction and protection extend only to the tangible.

Mindful of Derrida's warning, that "every archive [...] is at once institutive and conservative" (Derrida, 1995, 7), this exploration of the Italian literary Archive will start by describing the legislative framework that calls the archive and its contents under its purview. It will then proceed to discuss the main Italian collecting centres

2 On Maria Corti's life and work see Maria Corti: Congedi primi e ultimi, edited by Renzo Cremante and Angelo Stella, Cristina Nesi's Dialogo in pubblico, and special issue 47 of Autografo. 
and the web of connections that these have established with one another, and how these alliances have been transformed in the wake of the digital revolution.

Filiation and domiciliation and how these relate to law and place are overarching concerns in Derrida's Archive Fever, and by Corti's own admission in Ombre dal fondo, it was the realization that these notions are not necessarily bound by reciprocity that led her to conceive and create a safe haven from the dispersal of Italian authors' papers abroad. Yet the global reach of the laws of the marketplace test the resilience and porosity of geographical boundaries, expose the helplessness of legislative frameworks when these are not jolted into operation by vigilance, and highlight the complex relationship between the demands of transgenerational heritage, the pressure provoked by individual need, and the unpredictable mobility of people and ideas. This contribution will therefore discuss a number of case studies illuminating the experience of dispersal and geographical dislocation of Italophone authors' papers. Because of such an approach, this inquiry cannot make any claim to exhaustively mapping the pathways of dispersal and aggregation of Italophone authors' papers. It will however aim to identify the factors that determined the location of such collections, to highlight commonalities and challenges with regards to access, and to emphasize the positive organic relationship established between university institutions and archives in attracting, preserving, and organizing authors' papers in meaningful clusters while also promoting scholarly work around them.

\section{Law and Place}

The legislative context surrounding the Archive is important when considering the challenges facing different types of stakeholders operating in the Italian cultural field and the legacies to which these agents aim collectively to contribute. Italy is home to the highest number of UNESCO World Heritage Sites, ${ }^{3}$ and with a tangible heritage stretching back to pre-Roman civilizations, the nation has also an impressive wealth of documents, manuscripts, and artefacts that need protecting for future generations. Literary heritage and its assets are important elements of Italy's cultural wealth and multiple cultural and linguistic identities. It is thanks to the interplay between an established tradition in preservation and conservation (reflected in the special consideration given to the training of archivists since the post-Napoleonic age) (Tamblè, 1981; Duranti, 1988) and a literary scholarship which has long since embraced the pillars of genetic criticism, that the evidence of the evolution of an astonishing manuscript culture has been kept for future generations of readers and scholars. The duty to protect rare and precious manuscripts and autograph materials has been enshrined in legislation and subsumed in the responsibility for custodianship that the state extends to monuments and works of art. As such, these are subject to stringent legislation which originates - on the one side-from the privileged role enshrined by law to the Archivist in post-Unification Italy as custodian of historical memory, and

3 At time of publication: http://whc.unesco.org/en/list/stat. 
in part-on the other-from the Fascist regime's attempt at regulating preservation of different forms of heritage on the eve of Italy's entrance to the Second World War. Law n. 1089, entitled "Tutela delle cose d'interesse Artistico o Storico," ${ }^{4}$ published on June 1, 1939, stipulates in its first article that also "rare and precious" libraries, manuscripts, incunabula, and autographic materials such as correspondences fall under its purview. The law set out a notifying process, according to which both public and private institutions and private individuals alike, are obliged by law to declare to the state the possession of tangible heritage of historical significance; the legislator also emphasized the desirability of indivisibility with regards to collections of items of national historical relevance stating in no uncertain terms that the state and private entities should protect such assets against "dismemberment" and export.

This law is important insofar as it clearly defines the place of manuscript culture from any period within the definition of heritage assets, while also establishing the role of the state in protecting such objects. In doing so, the legislator acknowledged and identified the responsibilities of private institutions and individuals as custodians towards the safeguarding of manuscripts, libraries, and other items of national interest. Subsequently modified in 1976 and 2002, in its new version the law stipulated that the census responsibilities were to move away from the centre and be delegated to regional superintendencies, thus diluting and complicating the relationship between state and tangible assets, while strengthening the role played by regional stakeholders in preserving local heritage of often international significance.

It is in response to the duty of preserving and perpetuating the integrity of and accessibility to historical and cultural memory captured in correspondence and authors' papers that some archives have transformed themselves into collecting institutions when estate executors of twentieth-century literary personalities have transferred the responsibility of preservation onto better-equipped centres. It is important to note that the types of institutions involved in the custodianship of twentieth-century authors are diverse. With over six thousand municipal archives, ninety-five state archives in as many provinces, and forty historical sections of state archives in as many centres of national importance, it is not uncommon that an institution devoted to the preservation of the universality of documents produced by state offices-under special circumstances-may become the repository for authors' papers of outstanding cultural interest, especially when the author or their estate executor is unable to turn the author's residence into a museum and archive, following the example of a few significant models. ${ }^{5}$

This change in collection policies of state, regional, and provincial archives reflects the change of status of fonds of literary nature linked to a single personality

\footnotetext{
4 "The protection of objects of artistic or historical interest."

5 With regard to twentieth-century authors in Italy, there are several examples showing how the author's residence can be turned into a museum with archival facilities. The most successful models for such integration and convergence of Arkhé and Arkheion are Gabriele D'Annunzio's Vittoriale degli Italiani in Gardone Riviera, and the Archivio e Fondazione Benedetto Croce, where Croce's Neapolitan residence hosts the philosopher's personal library, his massive
} 
(or subject producer) within Italian archival science. A still-contested attribution, since the 1960s scholars have increasingly used the term "archive" to define a fonds of literary nature, composite structure (including in some cases personal libraries, correspondences, and drafts), and with no claim to exhaustively documenting every phase and aspect of a person's life and work (Trevisan, 2009). In order to protect such collections from fragmentation, dismemberment, and dispersal, state archives increasingly extended their protection to twentieth-century fonds of exceptional cultural importance. Often the donation, deposit, or sale is influenced by attachment to the birthplace or the town of longer residence. These affective considerations strengthen the local heritage dimension of the collection confirming the role played by writers and cultural personalities in the intellectual milieu of the city and the region. There is, for instance, the case of the papers of Anna Maria Ortese (Rome 1914-Rapallo 1998) which were bequeathed to the State Archive in Naples by her niece in 2002, a donation which was intended to honour Ortese's longstanding relationship with the city. By some it was felt as a reparation, a posthumous prodigal return, in the light of the controversies that surrounded Ortese's Il mare non bagna Napoli (1953) and her subsequent abandonment of the city in 1955. Alongside the State Archives, authors' papers have been collected or bequeathed to local and national libraries, and increasingly to archival institutions linked to or embedded in universities, like, for instance, the Fondo Guido Gozzano (Turin 1883-1916) donated by his brother to the Faculty of Letters of the University of Turin and around which the Centro per lo studio della letteratura del Novecento has developed since 1969.

An important role is also played by Italian publishers' archives, given the fruitful collaboration established between firms, intellectuals, and writers who managed to influence the aesthetic ethos of important publishers' catalogues. In this particular context, valuable collections are held at the Fondazione Arnoldo e Alberto Mondadori in Milan (est. 1979), the firm archive of Giulio Einaudi Editore, on deposit at the State Archives in Turin since 1983, the Bompiani archive on deposit at the Fondazione Corriere della Sera in Milan since 2001, and the Archivio Laterza in Bari. The holdings of these institutions contribute to tracing a complex image of the cultural and economic factors shaping literary communication in twentieth-century Italy and contribute to the understanding of the influence exerted by writers such as Benedetto Croce (Laterza), Italo Calvino, Cesare Pavese, Natalia Ginzburg (Einaudi), Anna Banti (Vallecchi), and Elio Vittorini (Mondadori and Einaudi) among many. In such a fragmented field, a number of institutions have acquired pre-eminence and have led by example the national collecting policies on Italian twentieth-century literary culture. These are the Centro Manoscritti of the University of Pavia (est. 1973), the Archivio Contemporaneo Bonsanti in Florence (est. 1975), and the Archivio del Novecento Letterario, based at the University of Rome, La Sapienza (est. 1997),

personal archive, and a centre for post-graduate specialization. To these examples one can add the Casa Museo Marino Moretti in Cesenatico (est. 1984), and the Archivio Primo Conti in Fiesole (est. 1980), where the painter's residence accommodates a personal museum and an archive holding important collections and correspondences linked to the Futurist movement. 
which between them preserve and regulate access to more than 370 collections of authors' papers of outstanding national significance.

\section{Archives and Institutions}

The story of the conception in 1969 and launch in 1973 of the University of Pavia's Centro Manoscritti is intimately linked to the extraordinary intellectual and persuasive abilities of Maria Corti (Milan 1915-2002). A textual philologist who was pivotal in importing structuralism into Italy through research protocols and a concerted programme of translations of the key classics, Corti also patronized authors, launched important and long-lasting scholarly journals (Strumenti critici, Alfabeta, Autografo), and collaborated with several publishing houses and newspapers. A novelist in her own right, Corti established long and profound friendships with the most important intellectuals and writers of her time. It is thanks to her personal cultivation of trust and to the respect that her intellect and passion inspired, that the 1975 Nobel Laureate Eugenio Montale, Romano Bilenchi, Giorgio Manganelli, and others progressively donated their papers and personal libraries to Corti, thus allowing her to form a kernel of important authors' collections around which the Centro Manoscritti would develop. In her Ombre dal fondo, Corti describes the circumstances leading to the foundation of the Centro, the main actors and stakeholders, and the challenges ambitious archival institutions face in attracting, retaining, and preserving authors' papers in a field made increasingly competitive by the game-changing influence of private collectors and wealthy US-based repositories. It was thanks to targeted generous financial support provided by the University of Pavia and banking institutions, and to the admiration that Corti's charisma excited in many stakeholders, that the Centro Manoscritti could contend with more well-endowed bidders. Ombre dal fondo makes clear that the accumulation of authors' papers needed to go hand in hand with the development of an adequate infrastructure, trained human resources, and a sustained research culture that put the avant-texte at the centre of its protocols. After Corti's passing in 2002 and with the appointment of equally committed directors (Renzo Cremante, Angelo Stella, Maria Antonietta Grignani, and Clelia Martignoni), the Centro Manoscritti has continued to hold the status of Sancta sanctorum where most of the Italophone authors aspire to have their papers stored and studied. Housing more than 250 author collections (including the papers of 1986 Nobel Laureate for Medicine, Rita Levi-Montalcini), a number of personal libraries, and the archives of several literary journals, most of which are currently undergoing a programme of digitization with the launch of the initiative PAD-Pavia Archivi Digitali in 2013, the centre has been consolidated as a national hub for research excellence and curatorial best practice.

The role played by charismatic leadership cannot be underestimated in the establishment and foundation of collecting institutions that would achieve international fame and reach. Founded in 1818, Florence's Gabinetto Vieusseux has played a key role in the city's cultural life since its inception as a place of intellectual exchange between the local cultural elite and the transient cosmopolitan literary 
community. The Gabinetto became a collecting centre for twentieth-century Italian and foreign authors when, in 1980, its director Alessandro Bonsanti (Florence 19041984) donated to the institution his sprawling personal archive comprising a rich collection of correspondence and personal papers relating to his literary activity and directorship of several important literary journals. ${ }^{6}$ The Archivio Contemporaneo Bonsanti has attracted a considerable number of donations and deposits of notable twentieth-century authors, thus becoming the capstone of a considerable array of literary collections, including the archive of Florence-based publishing firm Vallecchi. Bonsanti's leadership, and the centre's outstanding reputation built upon the previous enlightened directorship of Bonaventura Tecchi and 1975 Nobel Laureate Eugenio Montale, who both strove to keep the Gabinetto a place of free cultural exchange, even during the Fascist years. The Archivio Contemporaneo Bonsanti preserves and regulates access to more than one hundred collections, mostly related to Florentine authors and intellectuals, but also some outstanding non-Tuscan authors such as Neapolitan playwright Eduardo De Filippo (Naples 1900-1984), novelist Carlo Emilio Gadda (Milan 1893-Rome 1973), and controversial playwright, poet, essayist, and film director Pier Paolo Pasolini (Bologna 1922-Ostia 1975) find their home in the Gabinetto. These are only some of the most renowned literary figures whose papers and correspondences the Gabinetto partly or entirely preserves. It is the national cultural value linked to the Gabinetto's illustrious leaderships and programme of valorization that has led so many authors and estate executors to entrust their papers to the institution.

A similar focus on twentieth-century Italian culture characterizes the Archivio del Novecento Letterario based at the University of Rome, La Sapienza. While the holdings are less numerous than those of the Centro Manoscritti and Gabinetto Viesseux, with twelve archives including the papers of novelists Paola Masino and Carlo Bernari, and literary critic Enrico Falqui, this particular collecting institution's proactive engagement with the opportunities for preservation and access linked to digitization has allowed it to widen its reach and influence beyond Rome. Founded in 1997, and absorbing within its folds the Archivio del Novecento founded in 1979 by academic Giuliano Manacorda, the institution is led by Francesca Bernardini and supported by La Sapienza, the Regione Lazio, and the receipt of grants from the European Commission. The Archivio del Novecento Letterario quickly established itself as one of the leading institutions of a digital consortium-Ad900- that brings together several archives across the peninsula. In the 1990s, the simultaneous digitization projects embarked upon by several of these institutions led to the realization that a connected digital highway was not only a possibility but a necessity. Carte d'autore is the digital portal that provides a unified point of access to the digitized collections and catalogues of eight archives (often linked to universities) from Genoa to Bari, via Rome. Rome is also the epicentre of a wider digital network connecting more than forty archival

6 For an overview of Bonsanti's work and cultural action see Alessandro Bonsanti: scrittore e organizzatore di cultura, edited by P. Bagnoli. 
institutions collecting documents illuminating Italian twentieth-century political culture, journalism, activism, and social history-Archivi del Novecento-a curatorial digitization initiative launched in 1999, supported by the European Commission. The Roman projects make the most of the rich library holdings available in the capital, as well as the digitization initiatives supported by the National Library, and the libraries and archives of the Senate and Parliament. It is believed that Ad900 and Archivi del Novecento will continue to attract affiliations, thus bringing to a digitally literate and scholarly trained user community a rich wealth of documentation detailing the most salient personalities of the twentieth century. Ambitious digitization projects, however, like Derrida's "ashes of the archive," reveal persisting asymmetries of access and funding, as well as uneven practices in preservation and cataloguing procedures across the peninsula. Established in 2011, the SAN-Sistema Archivistico Nazionale, powered by the Direzione Generale Archivi, constitutes an impressive metadigital highway connecting SIAS-Sistema informativo Archivi di Stato, the regional superintendencies, ApeX-the European Archives Portal, and a set of thematic portals leading to outstanding archival resources on Italian architecture, music, fashion, history, and literature. This structure allows the community of users to access a wealth of information on the diversified cultural enterprises of the Italian twentieth century, while providing an example of a state-sponsored archive-enhancing digital initiative. However, this project exposes old problems in new guises, such as safeguarding against digital vulnerabilities and the need for shared best practice in meta-data tagging. Repositories based in universities or supported by local authorities may adhere to similar enterprises but lack of funding and infrastructure may delay the fulfilment of such aspirations. Yet the digital Arkheion should not be welcomed acritically: its promise to bring together split collections and to activate new synergies through increasingly sophisticated search tools has to be set against its ability to create a new jurisdiction, impose a new notion of what is "archivable," and define what is deemed worthy of futureproofing and what is not.

\section{Geographical Dislocation of the Archive}

While Centro Manoscritti, Gabinetto Vieusseux, and several literary archives in Rome and in the many centres scattered across Italy often preserve impressive sets of correspondence and papers, the archive related to a single subject producer is often split across a multiplicity of repositories, thus reflecting the personality's engagement with a variety of subjects, firms, and stakeholders. Two case studies may help sharpen the focus on the factors determining the dispersal or dislocation of an author's papers, while highlighting the tension between Arkhé, the locus of commencement and affect, and the institutionalizing demands of the Arkheion.

Pier Paolo Pasolini's multifaceted intellectual trajectory managed to illuminate several fields of cultural production, including theatre, film-making, journalism, publishing, and literary praxis. Traces of his engagement can be found in the archives 
of several publishers (Garzanti, Einaudi, Mondadori), and of the production houses and actors he worked with (most notably Orson Welles). While a vast collection of letters is held at the Archivio Bonsanti in Florence, with some important drafts of his novels and poetry collections donated by his mother to the Centro Manoscritti, the biggest fonds was donated by the author to his muse, actress Laura Betti, who established a Centro Studi Pasolini in Rome, the city that welcomed the intellectual in the post-war years. Pasolini would immortalize Rome and its people in several of his novels, poems, and films, and in its hinterland he would be killed in 1975. In 2004, Betti donated the sprawling fonds to Bologna, Pasolini's birthplace. Located in Bologna's Cineteca, the Centro Studi has ever since engaged in a sustained scholarly outreach programme supporting initiatives on Pasolini's work.

The fact that Pasolini's papers are in their large part preserved in a dedicated archive (that has travelled from the national capital to one of the most renowned cultural centres of the country), and in other archives of national importance highlights the intellectual's canonical status. In 2011, the institutive function of the Arkehion was productively disturbed by the announcement of the opening of the Fondo Archivio Pier Paolo Pasolini in Casarsa della Delizia, which was subsequently declared a collection of national relevance. The hometown of Pasolini's mother, Casarsa features in Pasolini's early poetry as his own idealized place of commencement. The papers stored at Casarsa document an important phase of Pasolini's engagement with vernacular languages and with Friulian in particular: drafts of his early Friulian poetry collections sit alongside the full run (and related correspondence) of Stroligùt, the vernacular journal Pasolini founded and directed between 1944 and 1946. This new archive, located in a small village at the margins of national cultural life, productively illustrates the affective pull of place and language, while refracting Pasolini's role in national culture by highlighting his contribution to the recuperation of peripheral vernacular languages and their cultural traditions.

A similar tension between Arkhé and Arkheion can be found in the archival domiciles of diasporic author Luigi Meneghello's papers. A longstanding friend of Maria Corti, from 1983 Meneghello (Malo 1922-Thiene 2007) periodically donated parts of his personal archive to the Centro Manoscritti, including after Corti's death in 2002. His personal admiration for the Centro's research activities led him to make it the main beneficiary of his papers and patrimony. The Centro in turn initiated a programme of study, still in place, around the Meneghello collection which, to date, is one of the largest hosted by the Centro Manoscritti. This programme has also led to a number of conferences, edited collections, $\mathrm{PhD}$ theses, and the publication of several posthumous volumes emerging from his collection. ${ }^{7}$ Some of Meneghello's materials, including parts of his personal library are also stored at the Museo Casabianca in Malo, his birthplace. A sizeable portion of his personal

7 For a description and analysis on the Meneghello collections see Chiara Longo's "Il fondo Luigi Meneghello di Pavia: Inventario (1984-2001)" and Nicoletta Trotta's “Fra le carte di Luigi Meneghello," in Tra le parole della "virtù senza nome": La ricerca di Luigi Meneghello. 
correspondence was donated by the author in 1999 to the Biblioteca Bertoliana in Vicenza, the place of his early education, and is framed within the collection Scrittori Vicentini del Novecento, which holds the personal papers of twenty-nine Vicenzaborn writers, including Vittorio Tomizza, Goffredo Parise, and Guido Piovene. The Meneghello correspondence was opened to the public in 2016, following the author's dispositions, and has been enriched by his heirs' donation of Meneghello's correspondence with Katia Bleier, his wife and holocaust survivor. As in Pasolini's case, the locations of Meneghello's archival domicile are linked on the one side to the centre that stores the literary heritage of Italian twentieth-century national culture, and on the other to repositories linked to his biography and literary work: the Malo and Vicenza holdings emphasize Meneghello's relationship to his places of commencement and the vernacular traditions rooted in those lands, which were at the centre of his fictional world. However, a fourth pole complicates the mapping of Meneghello's archival traces: the Meneghello fonds at the University of Reading (UK), the place of the author's employment for over forty years and where he wrote most of his published works. Reading's Special Collections hold early drafts of his 1964 resistance novel I piccoli maestri, drafts of the English translation of I piccoli maestri by Raleigh Trevelyan (published by Michael Joseph in 1967), manuscripts of his 1974 autobiographical collection Pomo Pero, and drafts of reflections on Fascist education and the British university system published in 1975 as Fiori Italiani. This collection and its extra-territorial, transnational domicile reflects Meneghello's personal mobility and highlights his diasporic trajectory by emphasizing his relation to British literary culture.

\section{Archive Is a Foreign Land}

Even within the boundaries of a nation, the archival circuit can amplify the fragmentation of the documentary traces of a person's life, with each hub claiming a stake in its consistency, and each contributing to its framing within regional, national, and supra-national narratives of identity and tradition. A more acute sense of vulnerability (of the body politic and of the body of work) often accompanies the dismemberment and dispersal of an author's papers beyond national borders. The sale of Filippo Tommaso Marinetti's notebooks by his daughters to Yale's Beinecke Library sparked media outrage in 1979, while the acquisition by the Getty Research Institute in Los Angeles of his early writings and correspondence in 1987 attracted less coverage. A deeper wound seemed to be inflicted on the national pride when 1934 Nobel Laureate Luigi Pirandello's notebook and a small selection of papers were sold to Harvard's Houghton Library in 1968. The difference in response may be explained by the fact that beyond the Beinecke and the Getty, Marinetti's papers are still scattered across Italy and in the hands of private collectors, while Pirandello's body of work has been located, in the main, in his mansion in Rome since its donation to the State in 1938. Further aggravation was caused in 1986 by the donation of a large epistolary collection by Marta Abba, actress and Pirandello's muse, to Princeton University rather than to the Italian foundation. Financial 
transactions alone may not explain the considerations behind such high-profile cases: scholarship, high standards of conservation, and a vision that sees on the one side the authors as surpassing the strictures imposed by national concerns by virtue of their greatness, and on the other, their papers as a commodity and not as a material figment of national heritage, all contribute to feeding the centrifugal power of dispersal and to increasing the tension between affective considerations rooted in the Arkhé and the exclusionary requirements of the Arkheion. However, with personal and professional trajectories increasingly characterized by transnational mobility, it is difficult to allocate the Arkhé to a singular territory, linguistic tradition, or national culture. The factors determining the biographically motivated archival domiciles of Pasolini and Meneghello's work multiply in scale when observing the geography of location of the papers of journalist, intellectual, and academic Giuseppe Prezzolini (Perugia 1886-Lugano 1982) and novelist Carlo Coccioli (Livorno 1920-Mexico City 2003).

The launch in 1978 of Lugano's Fondo di documentazione storico-letterarioartistica del Novecento marked the beginning of a re-organization of the numerous literary fonds of Italian interest in Swiss libraries. In 2004, Lugano's Biblioteca Cantonale grouped the Italophone collections under the name of Archivio Giuseppe Prezzolini, the most conspicuous fonds among the twenty-one Italophone literary archives and thirty-four minor collections constituting the extent of the repository. A transnationally mobile cultural operator, a prolific journalist, and cultural commentator of the first order, Prezzolini supported and founded important early twentieth-century Italian journals. His intellectual skirmishes with Benedetto Croce and Benito Mussolini are recorded in correspondence-a valuable source of documentation for the intellectual debates of the Fascist period-spreading over one thousand folders in Lugano, where he resided from 1968 until his death. Soon after Mussolini's rise to power, Prezzolini left Italy to move to Paris in 1925, and then in 1929 to New York, where he was appointed director of the Casa Italiana, the Italian Cultural Institute of Columbia University. Despite the distance, Italy continued to be at the centre of Prezzolini's interests, as an impressive collection of newspaper clippings collated between 1944 and 1963, currently held at the Center for Migration Studies in New York and spanning more than fifteen boxes, amply testifies. A substantial collection of his correspondence is held at the Rare Book and Manuscript Library at Columbia University, testifying to Prezzolini's transatlantic dialogue with many intellectuals engaged in the antifascist struggle and in the reconstruction of the country after the Second World War.

If Prezzolini left Italy for fear of persecution, Carlo Coccioli's journey was motivated by intellectual restlessness, the desire for experimentation, and longing for sexual freedom which in turn thematically inflected his multilingual oeuvre. Author of the first overtly gay Italian novel, Fabrizio Lupo, composed in French and published in Paris in 1952, Coccioli combined the tropes of high modernism with language experimentation while reflecting on religious and sexual identity. In 1955, Coccioli moved from Paris to Mexico City, where he died in 2003, having spent intermittent long spells in Italy. In the Mexican capital, the Casa de La cultura Carlo 
Coccioli promotes research on his work while sheltering a set of personal papers and correspondence mainly in Spanish. The main core of Coccioli's collection is, however, preserved at the Harry Ransom Center in Austin, Texas. Drafts of his works in French, Spanish, and Italian, and his correspondence, are joined by a conspicuous collection of readers' letters, especially those of Catholic gay men responding emotionally to the spiritual dimension of Coccioli's work. Other correspondence with important Latin American intellectuals and publishers such as Abelardo Arias and Renato Pellegrini reveal Coccioli's militant role in supporting the translation of European queer authors (including, among many others, Julien Green and André Gide) within the Latin American context, and in facilitating a debate around queer visibility, spirituality, and activism. ${ }^{8}$ The location of the Harry Ransom Center is not such a biographically motivated and symbolically laden locus of conservation as the Biblioteca Marucelliana in Florence, where since 1985 a substantial collection of Coccioli's Italian and French papers has been preserved, alongside the precious medieval manuscripts the institution holds. It is nevertheless equally important as it reflects the inscription of Coccioli's work in a transnational narrative of enfranchizement within transnational gay culture and leftfield experimentalism. It is perhaps a fitting tribute to the ephemeral resistance of the Archive, to its ability to weave an enveloping narrative of identity and belonging, and to erect protective and defensive boundaries, that Coccioli's disjecta membra are preserved in institutions marked by such different legacies and histories.

The factors conditioning the dispersal of the collections here discussed, while allowing us to reflect on the many journeys that the material legacies of writers endure, often symmetrically reflecting the mobility of authors and the serendipity of fate, also force us to observe the profound radical meaning that the delicate ecology of conservation holds in today's world. The Archive is perpetuated by alliances between different stakeholders, protected by frameworks regulating preservation and access. Yet this language of negotiation and protection is not neutral; it is itself the result of coercive decision, a producer of institutional meaning, superimposing narratives of homology only rarely disconnected by the welcoming, within the archival space, of writings rooted in linguistic otherness, demanding inscription, and forcing new interpretations and connections. The tension between a national culture and multiple vernacular traditions-now enriched by the many languages and cultural experiences that the migration waves from Eastern Europe, Africa, and the Middle East have brought to Italy_characterizes both the Italian literary space and the archives that preserve the documents of such dialogue. Italy's fragmentation into many "small fatherlands" rooted in cultural diversity is reflected not only in the linguistic experimentation of many Italophone writers but crucially also in the archival space, where the memory of idioms and literary traditions (old, new, and in the making) is preserved.

8 For more information see Michael A. Johnson's "Archival Review of the Carlo Coccioli Collection." 
The nomadic dimension of many intellectual trajectories of Italian modernitywhether in response to persecution, curiosity, or economic need-is reflected often in the diasporic dispersal of its traces. The location of archival evidence tells a story of journey, discovery, and rescue that cannot be left inert. It is the joint responsibility of scholars and archivists to bridge with connecting pathways different havens and to decode the new meanings that dislocation provokes into existence.

\section{Bibliography}

Bagnoli, Paolo, ed. Alessandro Bonsanti: scrittore e organizzatore di cultura. Florence: Festina Lente, 1990.

Caputo, Francesca, ed. Tra le parole della "virtù senza nome": La ricerca di Luigi Meneghello. Novara: Interlinea, 2013.

Corti, Maria. Ombre dal fondo. Turin: Einaudi, 1997.

Cremante, Renzo, and Angelo Stella, eds. Maria Corti: Congedi primi e ultimi. Novara: Interlinea, 2002.

Derrida, Jacques. Archive Fever: A Freudian Impression. Chicago: University of Chicago Press, 1995.

Duranti, Luciana. "Education and the Role of the Archivist in Italy." The American Archivist 51 (1988): 346-55.

Johnson, Michael A. "Archival Review of the Carlo Coccioli Collection." December 10, 2009. www.carlococcioli.com/download/contributi/20101002200301.PDF.

Longo, Chiara. "Il fondo Luigi Meneghello di Pavia: Inventario (1984-2001)." In Tra le parole della "virtù senza nome": La ricerca di Luigi Meneghello, edited by Francesca Caputo, 201-46. Novara: Interlinea, 2013.

Maria Corti: Ancora dialogando. Special issue of Autografo 47 (2012).

Nesi, Cristina. Dialogo in pubblico. Milan: Rizzoli, 1995.

Tamblè, Donato. "Archival Theory in Italy Today." Archival Science 1 (1981): 83-100.

Treanor, Brian. "What Tradition? Whose Archive? Blogs, Googlewashing, and the Digitization of the Archive." Analecta Hermeneutica 1 (2009): 231-41.

Trevisan, Myriam. Gli archivi letterari. Rome: Carocci, 2009.

Trotta, Nicoletta. "Fra le carte di Luigi Meneghello." In Tra le parole della "virtù senza nome": La ricerca di Luigi Meneghello, edited by Francesca Caputo, 247-83. Novara: Interlinea, 2013.

“Tutela delle cose d'interesse Artistico o Storico." UNESCO. www.unesco.org/ culture/natlaws/media/pdf/italy/it_law1089_39_itorof.

"World Heritage List Statistics." UNESCO. http://whc.unesco.org/en/list/stat. 